\title{
Are Slovak farms financially healthier as a result of the Common Agricultural Policy of the European Union?
}

\author{
Tatiana Bencová ${ }^{1, *}$, Andrea Boháčiková $^{1}$, Marián Tóth ${ }^{1}$, and Diana Pindešová ${ }^{2}$ \\ ${ }^{1}$ Slovak University of Agriculture in Nitra, Faculty of Economics and Management, Department of \\ Finance, Tr. Andreja Hlinku 2, 94911 Nitra, Slovakia \\ ${ }^{2}$ AgroBioTech Research Centre, Tr. Andreja Hlinku 2, 94911 Nitra, Slovakia
}

\begin{abstract}
Research background: The main goal of the Common Agricultural Policy (CAP) is to support farmers and improve their productivity. Agriculture is a specific sector of the economy, characterized by income support for farmers to ensure the availability of quality food. However, the question remains whether Slovak farms are financially healthy under the influence of the reformed CAP of European Union (EU)?

Purpose of the article: The main goal of the article is to evaluate the financial health of Slovak farms using selected prediction techniques pointing to the impact of the CAP of EU.

Methods: We have used data obtained from the financial statements of Slovak farms in the years 2009-2020. The financial health of farms will be assessed using selected generally constructed models of multivariate discriminatory analysis (Altman Z-score, IN 05, Creditworthiness Index, Taffler model), but also prediction models that have been specially constructed for the Slovak agricultural sector, such as G-index and $\mathrm{CH}-$ index. To detect the statistical differences between the years 2009-2013 and 2014-2020 in the value of prediction models of farms were used statistical t-tests of conformity in the surveyed sample.

Findings \& Value added: The results can be evaluated on two levels. The first of them is a look at the analysis of the financial health of Slovak farms in the context of the interpretation of the regulations of the Common Agricultural Policy of EU. The second output is an evaluation of the financial health of farms in the selected time period.
\end{abstract}

Keywords: Financial health; Farms; Common Agriculture Policy; Prediction techniques

JEL Classification: $C 12 ; Q 14 ; G 33$

\footnotetext{
*Corresponding author: tatiana.bencova@uniag.sk
} 


\section{Introduction}

The objective of the company is to create benefits for the owners in the form of profit, which should be sustainable in the long run or to ensure the growing market value of the company. Due to the constantly changing economic and political environment, companies operating in the agricultural sector are under constant pressure to monitor, record and apply various methods of financial analysis, in order to identify possible financial problems of the company in the future. Despite the need of cost-effectiveness, the farm should operate in a sustainable and ecological way, in order to preserve biodiversity and the soil. For this reason, the public sector plays an irreplaceable and important role for the agricultural sector. The Common Agricultural Policy (CAP) enters into a relationship between society and agriculture through a set of measures, regulations and strategies to support farmers and maintain the competitiveness and sustainability of agriculture. The CAP has gone through a number of major reforms over the time, affecting the functioning and financing of the whole agricultural sector. The 2013 reform focused mainly on a more global and integrated approach and adjusted the main direction of the CAP for the period 2014-2020. The programme period has been extended, considering the pandemic coronavirus situation, with the objective to ensure the necessary predictability and certainty for European farmers until the end of 2022, when the new Common agricultural policy enters into force. The reforms under the CAP aim at providing the financial support for farmers through direct payments. The "Report on Agriculture and Food sector in the Slovak Republic for the year 2019" shows that agriculture sector in 2019 achieved a profit before taxes in the value of 83 mill. $€$. However, in comparison with the 5-year average (2014-2018), the profit level was lower by almost 10 mill. $€$. The economic result has been affected by a decline in production, which subsequently reflected in a loss of sales, and could not have been compensated even by a slight increase in agricultural prices.

The main role in the economy of agricultural sector played the public supports, without which the majority of farms would suffer a loss. Almost $73 \%$ of the financial support of Slovak agriculture was provided from EU sources, and only part of the expenditures was co-financed from the state budget of the Slovak Republic. The percentage share of total support in revenues reached almost $35 \%$, and in direct payments $17.4 \% .^{\dagger}$ The economic results of farms have been affected by several income-cost and production factors, which had a significant impact on the overall financial health of companies. To the main factors belong the decline in the sector's production, decline in sales of own products, an increase in agricultural prices and cost factors, an increase in supports and the number of agricultural workers, a continuing trend of crop production dominance over the livestock production, a decline in hectare yields and cattle stocks, pigs and sheep, the negative impact of weather during the growing season, low interest rates with an impact on the increased credit burden of businesses, the application of rational measures to acquire new techniques and technologies, etc. Taking into account the mentioned facts, it can be clearly stated that the agriculture is a very specific sector within the national economy of Slovakia, where the economic results of the company are largely influenced by a number of exogenous (external) non-influencable factors. However, the question remains whether the farms operating in the Slovak Republic are financially healthier due to CAP instruments. The basic premise, which the authors of the study will analyse, is the assumption that farms in the period 2014-2020 show significantly different values of indicators of selected prediction models than in the previous period 2009-2013 (multiannual financial framework of CAP was set for 2007-2013, however, due to the availability of data, the period 2009-2013 has been chosen). Based on the assumption, the main objective of the paper was determined.

†file://D:/prevzate\%20subory/sprava_o_polnohospodarstve_a_potravinarstve_v_slovenskej_republik e_za_rok_2019.pdf 
The objective of the paper is to statistically verify whether there exist the differences between selected values of prediction models in the period 2014-2020, and in the previous period 2009-2013 and subsequently answer the established hypotheses concerning better financial health of farms in the programme period CAP 2014-2020.

The main objective of the paper is divided into partial objectives. The first partial goal is to create a literature review of studies that address the prediction of financial health in the agricultural sector. The second partial objective of the paper is to draw conclusions about the financial health of Slovak farms.

The source of data for the analysis is the financial statements compiled by farms in the years 2009-2020. For this reason, it is necessary to emphasize the weaknesses of financial reporting in the Slovak Republic. First of all, it is the historical focus of reporting in Slovakia and a strong tax orientation with the aim to visually decrease the economic result, which forms the basis for the payment of taxes. Also, in many cases, it is impossible to adjust the values of assets and liabilities towards their fair value.

\subsection{Literature review}

Nowadays, there exist a large number of prediction models that have been constructed during the certain period of time, in different economic and political conditions, and for different sectors of the economy. Their main idea is the prompt identification of possible financial problems of the company in the future. The initiators, in the field of construction models for predicting the financial health of companies, have become the authors in the 1930s of 20th century, during the Great Depression (Smith, Winakor, 1935, Merwin, 1942, Fitzpatrick P.J., 1932 and others). These papers were continuously followed by the papers of Beaver W.H. (1966), Altman E.I. (1968), Ohlson J.A. (1980), Tamarih M. (1976), Beerman M. (1982), whose constructed prediction models are an inspiration for other authors. The intention of the literature review is not to characterize the individual prediction models, rather to bring their summary in the agricultural sector.

Despite the increase in number of predictive studies in recent years, and their constant innovation in the application of innovative techniques for assessing the financial health of companies, it is necessary to state, that only a very small number of scientific studies focus. Moreover, these studies are in many cases limited to the use of multivariate discriminatory technique. Table 1 summarizes the prediction studies applied in the agricultural sector. Table 1 contains in the second column, after the authors of the study, the type of study T/P (Theoretical/Practical), or P (Practical). The mentioned characteristics of the study were added based on application, whether in the study new prediction models are constructed, in the next step verified, validated and implemented (studies Hampel et al. 2012, Vavřina et al., 2013, Stehel et al. 2019), whether the study is practical (P), aimed at verifying already created prediction models by other authors, e.g. Pompescu (2014), Grushnienie (2016), Rajin et al. (2016) and Karas et al. (2017). These studies verify already created prediction models, mostly the Altman's Z-coefficient $(1968,1983)$, and other constructed prediction techniques on new financial data of farms. The Table 1 also summarizes the applied prediction technique, the field of application, and summarizes the key results of the studies. 


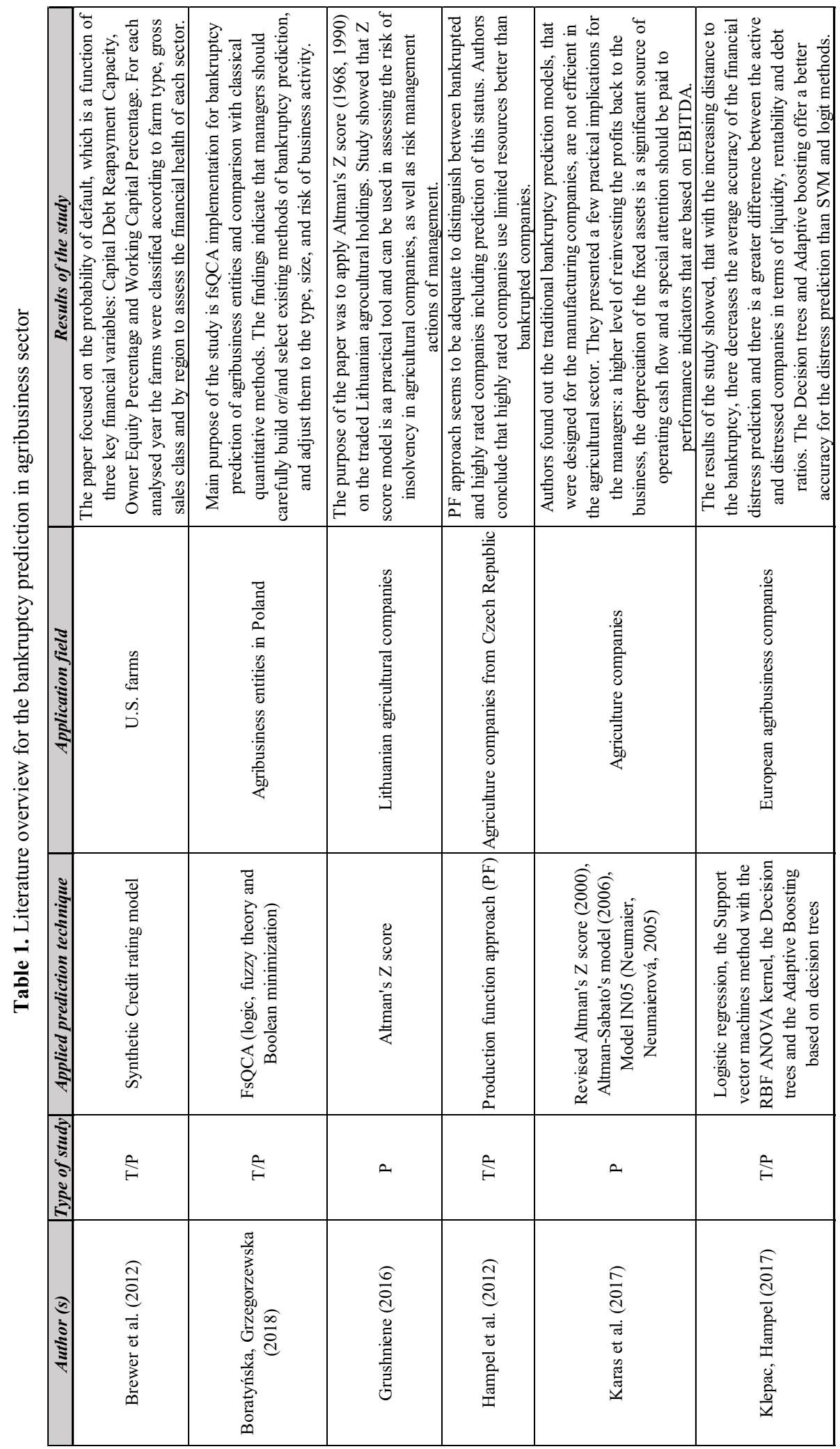




\begin{tabular}{|c|c|c|c|c|c|c|}
\hline & 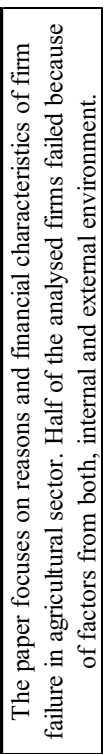 &  & 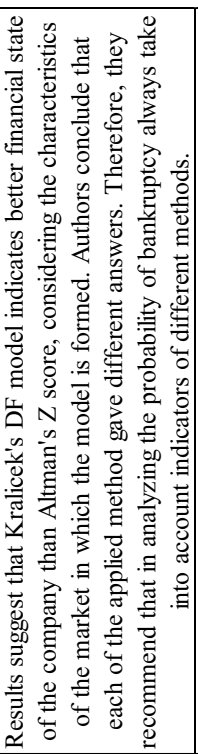 &  & 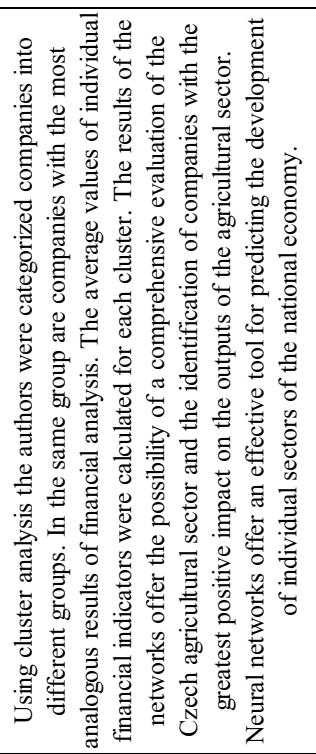 & 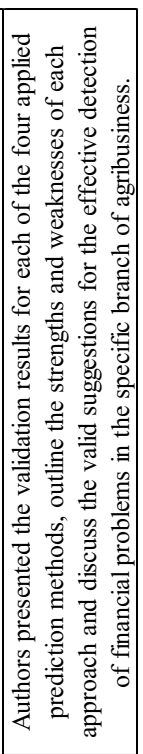 \\
\hline | & 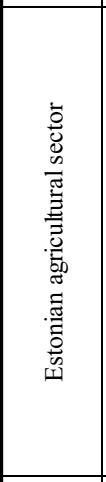 & 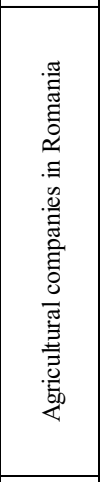 & 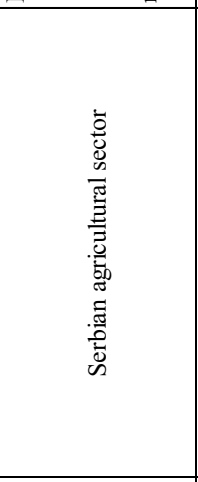 & 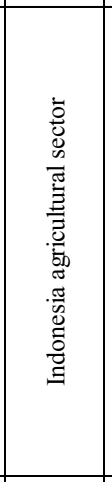 & 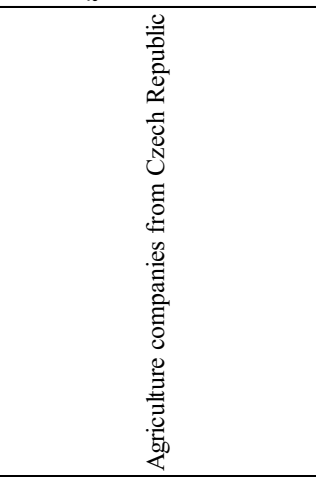 & 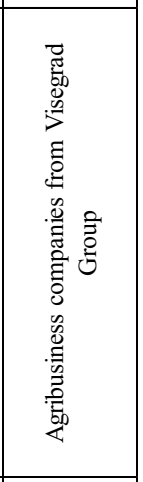 \\
\hline 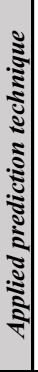 & ' & 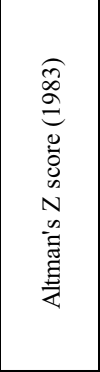 & 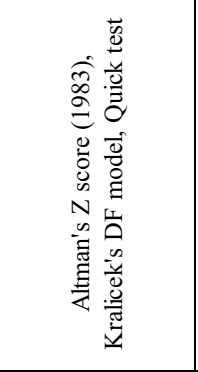 &  & 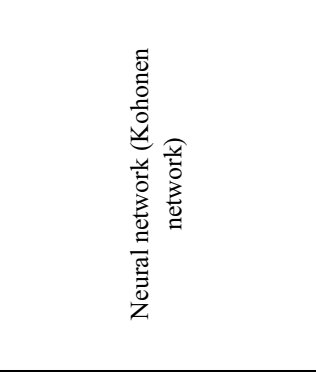 & 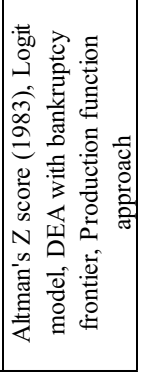 \\
\hline 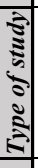 & $\stackrel{\vec{H}}{\vec{H}}$ & $a$ & $a$ & $\overrightarrow{\vec{H}}$ & $\stackrel{\vec{H}}{\vec{H}}$ & $\stackrel{\vec{H}}{\vec{H}}$ \\
\hline 梂 & 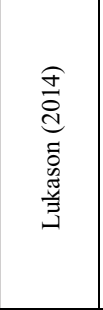 & 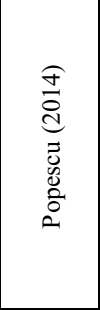 & 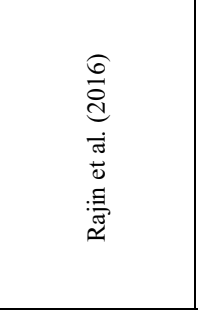 & 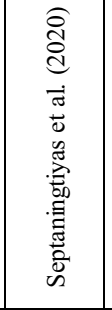 & 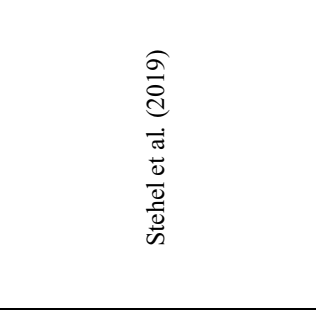 & 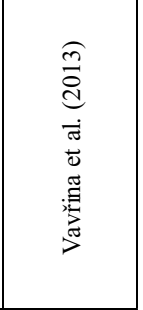 \\
\hline
\end{tabular}




\section{Methods}

According to the main objective of the paper, the main hypothesis has been stated. The main objective of the paper is to verify the statement that farms operating in the Slovak Republic are financially healthier due to the reformed Common Agricultural Policy of the European Union in years 2014-2020, compared to years 2009-2013. The statement can be confirmed or rejected by verifying the following hypothesis:

$H:$ We assume that the values of the determined prediction models for the assessment of the financial health of agricultural companies in the period 2014-2020 statistically significantly differ from the level of values in the period 2009-2013.

The tool for verifying the stated hypothesis is a t-test for equal mean values of two independent sets. The tested sets of companies are created as random selections. The application of the t-test for equal mean values requires firstly to evaluate the homogeneity of the variances of the two selected groups, which is verified on the basis of the Levene's test for equal variances of two sets. Levene's test for equal variances allows to confirm or reject the hypothesis of the equality of variances in the group of ratios of financial health of agricultural companies in 2014-2020 and in the group of companies in 2009-2013. The hypotheses of the Levene's test can be written as follows:

$$
\begin{aligned}
& \mathrm{H}_{0}: \delta_{1}^{2}-\delta_{2}^{2}=0 \\
& \mathrm{H}_{1}: \delta_{1}^{2}-\delta_{2}^{2} \neq 0
\end{aligned}
$$

where $\delta_{1}^{2}$ and $\delta_{2}^{2}$ are the variances of the basic sets of companies in two analysed periods, from which random selections are chosen.

The Levene's test is evaluated based on the p-value, which indicates the lowest possible level of significance for rejecting the null hypothesis. In the case of rejection of the null hypothesis, it is possible to assume the inequality of variances of the observed characteristic in the two analysed periods. Based on the evaluation of the test for equal variances, the choice of the test statistics of the t-test for equal mean values of two independent sets can be determined. The hypotheses of the t-test for equal mean values of two independent sets can be written as follows:

$$
\begin{aligned}
& \mathrm{H}_{0}: \mu_{1}^{2}-\mu_{2}^{2}=0 \\
& \mathrm{H}_{1}: \mu_{1}^{2}-\mu_{2}^{2} \neq 0
\end{aligned}
$$

where $\mu_{1}$ and $\mu_{2}$ are the mean values of individual sets of companies in two analysed periods, from which random selections are made. In the case of confirmation of equality of variances, the following testing statistics is used:

$$
t=\frac{\overline{x_{1}-x_{2}}}{s p \sqrt{\frac{1}{n_{1}}+\frac{1}{n_{2}}}}
$$

where

$$
s p=\sqrt{\frac{\left(n_{1}-1\right) s_{1}^{2}+\left(n_{2}-1\right) s_{2}^{2}}{n_{1}+n_{2}-2}}
$$


where $\overline{x_{1}}$ and $\overline{x_{2}}$ are sample arithmetic means of the two sets, $n_{1}$ and $n_{2}$ represent the number of observations in the individual sets, $s_{1}$ and $s_{2}$ are the sample standard deviations of the selected groups, and $s p$ is the common sample standard deviation.

In the case of rejection of the hypothesis for equal variances of the two selected groups, the testing statistics is expressed by the following relation:

$$
t=\frac{\overline{x_{1}-x_{2}}}{\sqrt{\frac{s_{1}^{2}}{n_{1}}+\frac{s_{2}^{2}}{n_{2}}}}
$$

where $\overline{x_{1}}$ and $\overline{x_{2}}$ are the sample arithmetic means of the two sets, $n_{1}$ and $n_{2}$ represent the number of observations in the individual sets, $s_{1}$ and $s_{2}$ are the sample standard deviations od selected sets. The results of the t-test for equal mean values of the two independent sets are also evaluated by comparing the p-values with the normal levels of significance. Based on the testing, the results of individual prediction models, which statistically significantly differ in the two examined periods, will be interpreted. The results will be supported by graphical interpretation of selected values of prediction models in two analysed periods.

Farm can be considered as an economic unit that differs in the structure of assets and liabilities, different economic activity within the agricultural sector, size, investment activity, size and quality of cultivated land, etc. The agricultural sector is particularly specific because of the different economic focus of the agricultural companies, concretely crop production, including vegetables and horticulture, livestock production, crop production combined with livestock production, services for crop and livestock production and hunting, game trapping and breeding, including related services. Purves et al. (2015) analyse the relationship between financial and non-financial factors of financial failure predictors in farms. It is not possible to state a generally valid prediction model for assessing the financial health of agricultural companies, because the existing prediction models were constructed for different time periods, in different political and economic conditions and for different sectors of the economy (Table 2). For this reason, two prediction models, constructed based on the discriminant analysis, specifically constructed for Slovak agricultural companies, were selected, namely the CH-index (1998) and the G-index (2002). Verification of both models (CH-index, G-index) in comparison with Altman's Z-score is analysed on a set of new data on farms in the studies Valášková et al. (2017) and Bod'a, Úradníček (2019). The authors discuss in the studies the suitability of its use for new financial data on agricultural companies, which has changed significantly in recent years due to transformational changes in the agricultural sector and the rules of the Common Agricultural Policy. Csikova et al. (2019) discuss the limitation of financial health prediction in companies from postcommunist countries V4.

All selected prediction models, which are summarized in Table 2 are constructed based on the multivariate discriminant analysis. The specification of financial variables of selected prediction models is shown in Table 3. 

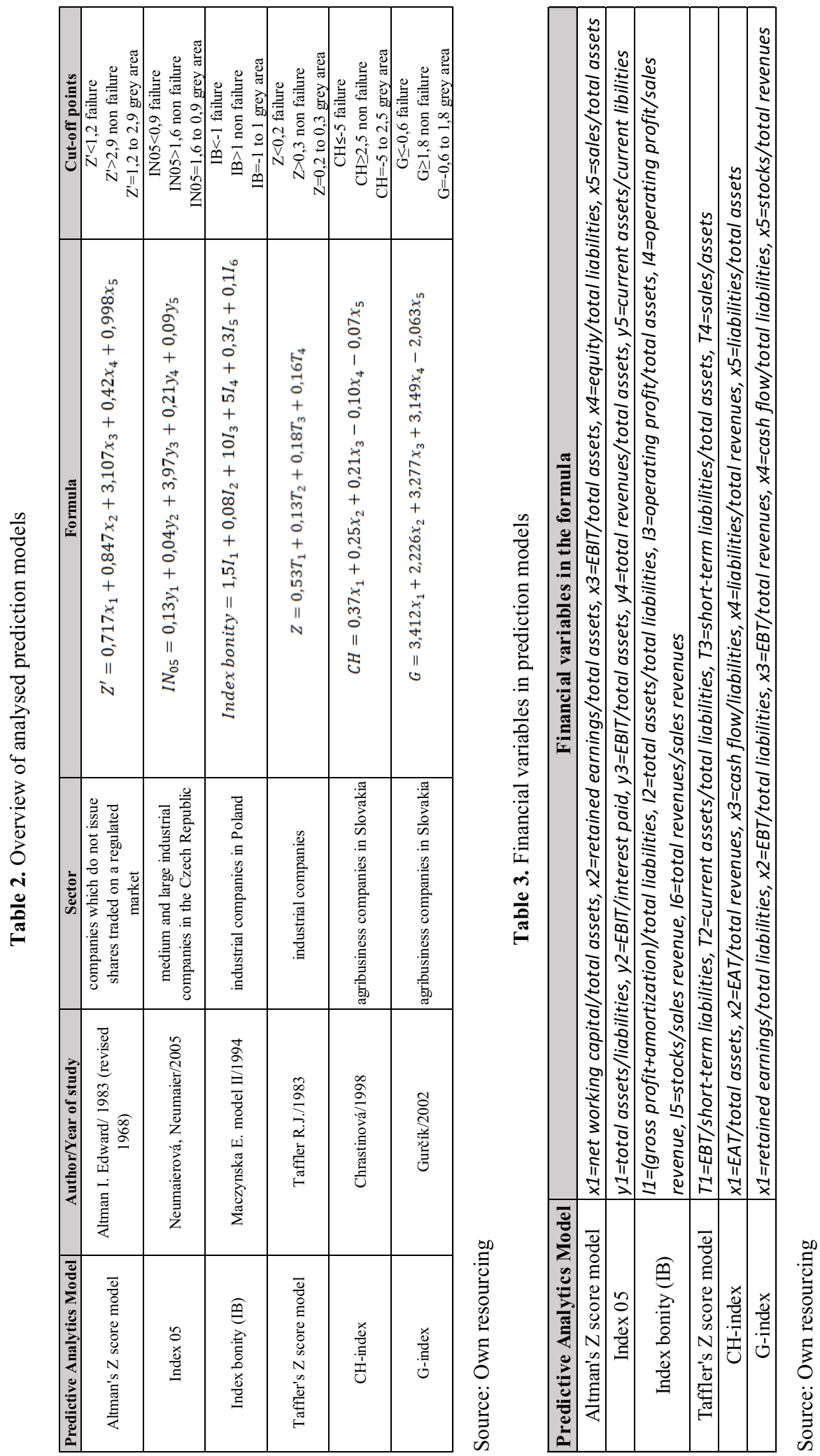


\section{Results and Discussions}

The intention of the following section is to identify significant statistical differences between the values of selected prediction models for the group of farms in 2009-2013 and the group of farms in 2014-2020, when a new reformed CAP was adopted. The ambition was to find connections in the aspects of the financial health of the farm with regard to the time factor. The sample sets of farms in two selected time periods were conceived by random selection from the basic set, while outliers were removed from both sample sets. All analysed farms operate in the field of agriculture and forestry, their ownership is cooperative or private and they perform their activities in various regions of the Slovak Republic. The homogeneity of the variances of the two selected groups was evaluated using the Leven's test for equal variances. Based on the results of Leven's test was conditioned the choice of a suitable t-test statistic for equal mean values. The results of the t-test for equal mean values of two independent sets were compared with the significance level $\alpha=0,05$.

A statistically significant difference at the significance level $\alpha=0,05$ between the mean value of the indicators in the group of farms in 2009-2013 and the group of farms in 20142020 was confirmed in the prediction models: Altman Z-score (1983), Taffler model (1983) and the G-index (2002). Based on these prediction models, it can be assumed that the level of values of the determined prediction models for assessing the financial health of farms in the period 2014-2020 differs statistically significantly from the level of values in the period 2009-2013. It follows that the reforms adopted under the Common Agricultural Policy for 2014-2020 had an impact on the resulting values of the financial health of farms, as they were statistically significantly different from the values in the previous time period. The process of globalization and mutual integration of the rules and settings of the CAP in the countries of the European Union, taking into account selected prediction techniques, was also reflected in the values of the financial health of Slovak farms.

However, the question remains whether the CAP had a positive or negative impact on the resulting values of the financial health of farms. Comparing the average values of the Altman Z-score model (1983) in 2009-2013 and in 2014-2020, we came to the conclusion that the arithmetic mean of financial health values in 2014-2020 was lower than in the previous period, which may indicate deteriorating financial health of farms. In the case of comparing the average values obtained using the Taffler model (1983), we can state higher average values of financial health in the years 2014-2020, which may, on the contrary, indicate better financial health of farms by adopting a reformed CAP. The average values of financial health obtained using the G-index (2002) also refer to the deteriorating financial health of farms in 2014-2020. The resulting values of financial health obtained using the Altman Z-score model and the G-index placed farms in the grey zone, while the results obtained using the Taffler model ranked farms among the prosperous companies.

Agriculture is a specific sector of the country's economy, and even interventions in the form of the CAP and the resulting support for farmers do not necessarily mean that farms will be categorized as financially healthy.

\section{Conclusions}

The main idea of the presented paper was to verify whether the processes of globalization within the setting of new rules of the reformed CAP in the EU countries in 2014-2020 have an important impact on the values of financial health of farms in the Slovak Republic compared to the previous time period 2009-2013. For this purpose, six prediction models based on multivariate discriminant analysis were selected, of which two models were 
specifically constructed in the conditions of Slovak farms. Using a t-test for equal mean values of two independent sets, we came to the conclusion that there are statistically significant differences between the values of financial health in 2009-2013 and 2014-2020 in the case of calculation based on Altman Z-score coefficient (1983), Taffler model (1983) and G-index (2002). However, by a more detailed analysis of the average values of the financial health of farms using the Altman Z-score model and the G-index, we came to the conclusion about the deteriorating financial health of farms in 2014-2020. It is important to note that the prediction models used in the study were constructed for different industries, in different economic conditions and for different time periods. Due to its dependence on financial aid under CAP rules, agriculture is a specific sector that is subject to turbulent changes resulting from a number of uncontrollable factors, such as climate change, weather changes, changes in agricultural commodity prices, changes in input commodity prices and more others. For this reason, it is necessary to incorporate these changes into the prediction techniques and focus on the application of innovative techniques (support vector machines, neural networks, decision trees and DEA models) of financial health assessment on a set of farms.

Further research in this area will focus on comparing the values of financial ratios in the group of financially healthy farms and the group of farms in financial distress in both time periods examined and to identify possible causes of deteriorating financial health of farms.

\section{Acknowledgements}

The article was supported by scientific project VEGA 1/0735/21 with the title Role, financial needs and risks of small farms in Slovakia.

This publication was supported by the Operational Programme Integrated Infrastructure within the project: Demand-driven research for the sustainable and innovative food, Drive4SIFood 313011V336, co-financed by the European Regional Development Fund.

\section{References}

1. Altman, E. I. (1968). Financial ratios, discriminant analysis and the prediction of corporate bankruptcy. The Journal of Finance, 23(4), 589-609.

2. Beaver, W. H. (1966). Financial ratios as predictors of failure. Journal of Accounting Research, 4, 71-111.

3. Bod'a, M., \& Úradníček, V. (2019). Predicting financial distress of Slovak agricultural enterprises. Ekonomický Časopis, 67(4), 426-452.

4. Boratyńska, K., \& Grzegorzewska, E. (2018). Bankruptcy prediction in the agribusiness sector: Lessons from quantitative and qualitative approaches. Journal of Business Research, 89, 175-181.

5. Brewer, B. E., Wilson, C. A., Featherstone, A. M., Harris, J. M., Erickson, K., \& Hallahan, C. (2012). Measuring the financial health of US production agriculture. Journal of ASFMRA, 178-193.

6. Chrastinova, Z. (1998). Methods of Assessment of Economic Solvency and Prediction of Financial Situation of Agricultural Enterprises. Bratislava: VUEPP.

7. Csikosova, A. Janoskova, M., \& Culkova, K. (2019). Limitation of financial health prediction in companies from Post-Communist countries. Journal of Risk and Financial Management, 12(15), 1-14.

8. Gurcik, L. (2002). G-index-The financial situation prognosis method of agricultural enterprises. Agricultural Economics, 48(8), 373-378. 
9. Hampel, D., Vavrina, J., \& Janová, J. (2012). Predicting bankruptcy of companies based on the production function parameters. In 30th international conference mathematical methods in economics. Karviná: Silesian University in Opava, School of Business Administration.

10. Karas, M., Reznakova, M., \& Pokorny, P. (2017). Predicting bankruptcy of agriculture companies: Validating selected models. Polish Journal of Management Studies, 15.

11. Kiaupaite-Grushniene, V. (2016). Altman Z-score model for bankruptcy forecasting of the listed Lithuanian agricultural companies. In 5th International Conference on Accounting, Auditing, and Taxation (ICAAT 2016) (pp. 222-234). Atlantis Press.

12. Klepac, V., \& Hampel, D. (2017). Predicting financial distress of agricultural companies in EU. Agricultural Economics - Czech, 63, 347-355.

13. Lukason, O. (2014). Why and how agricultural firms fail: evidence from Estonia. Bulgarian Journal of Agricultural Science, 20(1), 5-11.

14. Maczynska, E. (1994). Assessment of the condition of the enterprise. Simplified methods. Zycie Gospodarcze, 38, 42-45.

15. Neumaierová, I., \& Neumaier, I. (2013). Vypovídací schopnost Indexu IN05. In Ekonomika $v$ pohybu: Sborník príspěvků $\mathrm{z}$ mezinárodní konference pořádané u prŕíležitosti šedesátého výročí VŠE a fakulty [Economy in motion: Proceedings from the international conference organized on the occasion of the 60th anniversary of University of Economics and the faculty], Prague: Prague University of Economics and Business, 169-176.

16. Pacáková, V., Labudová V., Sipková, L., Šoltés, E., \& Vojtková, M. (2009). Štatistické metódy pre ekonómov. 411.

17. Popescu, A. (2014). Research regarding the use of discriminant analysis for assessing the bankruptcy risk of agricultural companies. Scientific Papers, Series Management, Economic Engineering in Agriculture and Rural Development, 14(4).

18. Purves, N., Niblock S. J., \& Sloan, K. (2015). On the relationship between financial and non-financial factors: A case study analysis of financial failure predictors of agribusiness firms in Australia. Agricultural Finance Review, 75(2), 282-300.

19. Rajin, D., Milenković, D., \& Radojević, T. (2016). Bankruptcy prediction models in the Serbian agricultural sector. Economics of Agriculture, 63(1), 89-105.

20. Septaningtiyas, I. E., Utami, E. S., \& Sumani, S. (2020). Financial distress prediction on agricultural sector companies in Indonesia stock exchange. International Journal of Research Science and Management, 7(1), 155-159.

21. Správa o polnohospodárstve a potravinárstve $v \quad$ SR za rok 2019. file://D:/prevzate\%20subory/sprava_o_polnohospodarstve_a_potravinarstve_v_sloven skej_republike_za_rok_2019.pdf.

22. Stehel, V., Horák, J., \& Vochozka, M. (2019). Prediction of institutional sector development and analysis of enterprises active in agriculture. Business Administration and Management, 24(4), 103-118.

23. Taffler, R. J. (1983). The assessment of company solvency and performance using a statistical model. Accounting and Business Research, 13(52), 295-358.

24. Valášková, K., Švábová, L., \& Durica, M. (2017). Verification of prediction models in conditions of slovak agricultural resort. Economics, Management, Innovation, 9(3), 3038 . 
25. Vavřina, J., Hampel, D., \& Janová, J. (2013). New approaches for the financial distress classification in agribusiness. Acta Universitatis Agriculturae et Silviculturae Mendelianae Brunensis, 61(4), 1177-1182. 